\title{
Th1-like dominance in high-risk first-degree relatives of Type I diabetic patients
}

\author{
M. G.E. Karlsson, S. Sederholm Lawesson, J. Ludvigsson \\ Department of Health and Environment, Division of Paediatrics, Faculty of Health Sciences, Linköping University, \\ Linköping, Sweden
}

\section{Abstract}

Aims/hypothesis. The humoral part of the immune system, including autoantibodies, is known to predict manifest Type I (insulin-dependent) diabetes mellitus in first-degree relatives but the cell-mediated immune process preceding the manifest disease still is not known. The aim of this investigation was to estimate the immunological balance of Th-like lymphocytes (Th1/Th2) in high-risk first-degree relatives of Type I diabetic children.

Methods. Peripheral blood mononuclear cells (PBMC) from 21 healthy high-risk first-degree relatives $(I C A \geq 20)$ were examined and compared with the response seen in PBMC from children with newly diagnosed Type I diabetes and healthy control subjects of similar age, sex and HLA-type. Expression of interleukin-4 (IL-4) and interferon- $\gamma$ (IFN- $\gamma$ ) mRNA were determined by RT-PCR and as protein by ELISPOT after stimulation with specific epitopes of $\mathrm{GAD}_{65}$ (a. a. 247-279, 509-528, 524-543), bovine serum albumin, the ABBOS peptide (a.a. 152-169) and insulin.
Results. High-risk relatives had a high ratio of IFN$\gamma:$ IL-4 compared with both diabetic children $(p=0.0005)$ and healthy control subjects $(p=0.004)$. Production of IFN- $\gamma$ seen in high-risk relatives was negatively correlated to production of GADA $(r=-0.44, p=0.05)$. The high concentration of IFN$\gamma$ from high-risk relatives, decreased after stimulation with peptides of $\mathrm{GAD}_{65}$, the ABBOS peptide, BSA and insulin. Increased secretion of IL-4 was observed after stimulation with two peptides of $\mathrm{GAD}_{65}$ (a.a. 509-528 and 524-543), the ABBOS peptide and insulin.

Conclusion/interpretation. Overwhelming production of IFN- $\gamma$ seen in peripheral blood mononuclear cells from high-risk first-degree relatives of children with Type I diabetes suggests a Th1-like immune deviation in the prediabetic phase. [Diabetologia (2000) 43: 742-749]

Keywords Type I diabetes, Th-lymphocyte, high-risk relatives, IFN- $\gamma$, IL-4, GAD ${ }_{65}$, ABBOS, BSA, insulin, GADA.
Received: 10 December 1999 and in revised form: 29 February 2000

Corresponding author: M. Karlsson, Clinical Research Centre, Division of Paediatrics, Faculty of Health Sciences, S-581 85 Linköping, Sweden

Abbreviations: $\mathrm{Cu}, \mathrm{ZnSOD}$, Copper-zink superoxide dismutase; ELISPOT, enzyme-linked immuno spot; ENDIT, European nicotinamide diabetes intervention trial; GADA, glutamic acid decarboxylase autoantibody; IAA, insulin autoantibody; ICA, islet cell antibody; IFN- $\gamma$, interferon gamma; PHA, phytohaemagglutinin; Th, T-helper; PBMC, peripheral blood mononuclear cells; mAB, monoclonal antibody; IJDF, International Juvenile Diabetes Foundation; NOD, non-obese diabetic.
The insulitis at onset of Type I (insulin-dependent) diabetes mellitus is characterised by infiltration of mononuclear cells [1], especially lymphocytes [2]. The T-helper (Th) lymphocytes have been divided into two subpopulations, Th1 and Th2 [3], based upon their different pattern of cytokine production [4]. Although Th1-lymphocytes seem to dominate in autoimmunity there could well be a complex interplay between Th1 and Th2 cells [5] in which Th2-lymphocytes might even be protective [4].

Glutamic acid decarboxylase $\left(\mathrm{GAD}_{65}\right)$ causes both humoral immune response with production of auto- 
antibodies [6-9] and proliferation of Th1-like lymphocytes [4] in Type I diabetic patients. A specific peptide of $\mathrm{GAD}_{65}$ (amino acids 247-279), similar in the amino acid sequence to Coxsackie B virus (a.a. 32-47) $[8,10,11]$, could be one reactive epitope which triggers the immune response in a Th1-like manner [12, 13]. Furthermore, another epitope of $\mathrm{GAD}_{65}$ (a.a. 509-524) that shares the sequence homology with adenovirus, cytomegalovirus and Epstein-Barr virus [14] and also with proinsulin (a.s. 24-36) [15] has been shown to cause an immune response in human Type I diabetes [16]. The sequence (a.a. 524-543) next to this epitope has been shown to be able to delay the onset of diabetes and reduce its incidence in non-obese diabetic (NOD) mice [17].

Among dietary proteins, bovine serum albumin (BSA) from cows' milk has been suggested to be involved in the development of diabetes [18]. Special interest has been focused on the ABBOS peptide from BSA, suggesting this peptide as a possible trigger of the autoimmune response [19]. Both activated Th1-like and Th2-like lymphocytes from diabetic children as well as from healthy control subjects have been shown after stimulation with the ABBOS peptide [20]. These results suggest that the immune response to the ABBOS peptide is secondary either to intolerance towards cows' milk or to a non-specific up-regulation of the immune system [20].

First-degree relatives of Type I diabetic patients with a positive titre of islet cell antibody (ICA) ( $\geq 20 \mathrm{JDF}$ ) have been offered participation in the European Nicotinamide Diabetes Intervention Trial (ENDIT) [21]. The purpose of this study is to estimate the cell-mediated immune response to relevant antigens and the humoral immunity in these highrisk relatives.

\section{Material and methods}

Peptides and antigens. The three synthetic peptides of human glutamic acid decarboxylase $\left(\mathrm{GAD}_{65}\right)$, used in this study, are as follows; amino acids 247-279 (NMYAMMIARFKMFPEVKEKGMAALPRLIAFTSE-OH) molecular weight 3823.7, a.a. 509-528 (IPPSLRTLEDNEERMSRLSK-OH) molecular weight 2371.7, and a.a. 524-543 (SRLSKVAPVIKARMMEYGTT-OH) molecular weight 2238.7, (Dept. of Medical and Physiological Chemistry, University of Uppsala, Sweden). Furthermore, the ABBOS peptide, a.a. 152-169 (FKADEKKFW GKYLYE IAR) [22] which was kindly provided by Professor Dosch, insulin (Actrapid Novo Nordisk, Bagsvaerd, Denmark), BSA (Sigma, Stockholm, Sweden) and phytohaemagglutinin (PHA) (Sigma) were all included in this investigation.

Peripheral blood mononuclear cells from high-risk relatives, diabetic children and healthy control subjects. Sodium heparinised venous blood samples were obtained 6 months after inclusion in the ENDIT trial from 21 first-degree relatives ( 9 women; age $9-47$ years and 12 men; age $7-48$ years) of Type I dia- betic patients. These high-risk relatives had ICAs of 20 International Juvenile Diabetes Foundation units (IJDF-U) or more and five of them have so far developed Type I diabetes. Blood samples from one woman (41 years) and from one girl (11 years) were taken at the time of diagnosis, whereas blood samples from two boys (13 and 16 years) and one man (51 years) were taken before the development of Type I diabetes.

Blood samples were collected from six diabetic children (three girls; age 8-16 years and three boys; age 4-16 years) 4 days after the onset of initial insulin therapy. Out of six diabetic children five had the diabetes-associated HLA-types DR3 or DR4 or both and DQ0301-0302 or DQ0501-0201 or both. Blood samples were also collected from six healthy control subjects (three women; age 21-49 years and three men; age 14-51 years) matched for the diabetes-associated HLAtypes DR3, DR4 or DR3/4. The healthy control subjects did not have diabetes or any other autoimmune disease. Blood samples, from participants attending the ENDIT trial, were transported at room temperature to Linköping within $24 \mathrm{~h}$, whereas blood samples from children with Type I diabetes were taken when visiting the diabetes team at the paediatric clinic. Peripheral blood mononuclear cells (PBMC) were isolated by Ficoll-Paque density gradient centrifugation (Pharmacia, Biotech, Uppsala, Sweden) and cryopreservated in nitrogen until stimulation.

Peripheral blood mononuclear cells stimulated with peptides associated with Type I diabetes. Frozen mononuclear cells were thawed, directly from $-196{ }^{\circ} \mathrm{C}$ to $+37^{\circ} \mathrm{C}$, in a water bath during addition of RPMI 1640 supplemented with $10 \%$ FCS. The cell pellet was diluted in AIM V research grade (Gibco, Täby, Sweden) supplemented with $2 \mathrm{mmol} / \mathrm{l} \mathrm{L}$-glutamine, $50 \mu \mathrm{g} / \mathrm{l}$ streptomycin sulphate, $10 \mu \mathrm{g} / \mathrm{l}$ gentamicin sulphate and $2 \times 10^{-5} \mathrm{~mol} / \mathrm{l}$ 2-mercaptoethanol (Sigma). We stimulated $4 \times 10^{6} \mathrm{PBMC}$ with $50 \mu \mathrm{g} / \mathrm{ml}$ insulin (Actrapid), with $\operatorname{GAD}_{65}$ (a.a. 247-279) or with the ABBOS peptide (a.a. 152-169) [22] at a concentration of $5 \mu \mathrm{g} / \mathrm{ml} \mathrm{[23]} \mathrm{for} 48 \mathrm{~h}$ at $37^{\circ} \mathrm{C}$, in $5 \% \mathrm{CO}_{2}$. We used PBMC, from each high-risk relative and healthy control subject, incubated without antigen but otherwise under the same conditions, as a control for quantification of spontaneous mRNA expression for IFN- $\gamma$ and IL-4.

RNA isolation and $c D N A$ synthesis. Total RNA was isolated from PBMC with RNAzol B (AMS Biotechnology, Täby, Sweden) as recommended by the supplier except for small changes [12]. Total RNA was quantified by optical density at $260 \mathrm{~nm}$. Using equal amounts of total RNA $(2 \mu \mathrm{g} / \mu \mathrm{l})$ from PBMC, stimulated under various conditions, complementary DNA (cDNA) was synthesised by reverse transcription as described previously [13]. The cDNA was diluted in water (free from RNase) in concentrations $1: 1(0.1 \mu \mathrm{g} / \mu \mathrm{l}), 1: 5(0.02 \mu \mathrm{g} / \mu \mathrm{l}), 1: 25$ $(0.004 \mu \mathrm{g} / \mu \mathrm{l})$ and 1:250 $(0.0004 \mu \mathrm{g} / \mu \mathrm{l})$ of total RNA. The final cDNA product was stored at $-20^{\circ} \mathrm{C}$ for subsequent cDNA amplification by polymerase chain reaction.

Polymerase chain reaction (PCR). The PCR reaction mixture was amplified with a Perkin Elmer (Stockholm, Sweden), DNA thermal cycler 2400 , for 38 cycles with an annealing temperature of $55^{\circ} \mathrm{C}$ for interferon gamma (IFN- $\gamma$ ) and $60^{\circ} \mathrm{C}$ for IL-4 and copper-zinc superoxide dismutase ( $\mathrm{Cu}, \mathrm{ZnSOD})$. In all experiments, controls without template were included. Primer sequences for the internal control, $\mathrm{Cu}, \mathrm{ZnSOD}$ and for cytokine-specific primer sequences for interleukin-4 (IL-4) and IFN- $\gamma$ have been described previously [12]. The predicted sizes of the single PCR products are: Cu,ZnSOD, 393 bp [24]; IL-4, 176 bp [25] and IFN- $\gamma, 129$ bp [26] according to the hu- 
man cDNA. Interferon gamma and IL-4 primers were designed as described previously [27] in such a way that they anneal to sequences located in different exons, thus making it possible to distinguish by size, amplified cDNA from amplified contaminating genomic DNA. The cDNA products and a molecule weight ladder were visualised by gel electrophoresis in $1.6 \%$ agarose (KEBO, Stockholm, Sweden) in $0.5 \times$ TRIS-borate/EDTA buffer after ethidium bromide (Sigma) staining and photographed under UV light.

Expression of cytokine mRNA from PBMC stimulated with specific antigen was scored and presented as positive/negative after subtraction of the mRNA expression detected from unstimulated lymphocytes.

Stimulation of lymphocytes and enumeration of IFN- $\gamma$ and IL4 -secreting cells. The enzyme-linked immuno-spot (ELISPOT) was done as described previously [28] but slightly modified [29]. Sterile nitro-cellulose-bottomed 96-well microtitre plates (Multiscreen HA, Millipore, Bedford, Mass., USA) were coated with $15 \mu \mathrm{g} / \mathrm{ml}$ of mouse anti-human IFN- $\gamma$ 7B61 monoclonal antibody (mAB) or mouse anti-human IL-4 mAB (Mabtech AB, Stockholm, Sweden) overnight at $4{ }^{\circ} \mathrm{C}$. Nonspecific binding sites on the nitro-cellulose were blocked by incubation with Iscove's modification of Dulbeccos medium (Life Technologies, Täby, Sweden) supplemented with $50 \mathrm{U} /$ $\mathrm{ml}$ penicillin, $50 \mu \mathrm{g} / \mathrm{ml}$ streptomycin (Life Technologies), $10 \mathrm{ml} / 1100 \times$ non-essential amino acids (Life Technologies) and $5 \% \mathrm{FCS}$, for $30 \mathrm{~min}$ at $37^{\circ} \mathrm{C}$.

Aliquots of $100000 \mathrm{PBMC} /$ well were applied together with $100 \mu \mathrm{l}$ of Iscove's modification of Dulbecco's medium with supplements including one of the following antigens: $100 \mathrm{pg} / \mathrm{ml}$ of $\mathrm{GAD}_{65}$; a. a. 247-279; a. a. 509-528; a. a. 524-543, $100 \mathrm{pg} / \mathrm{ml}$ of the ABBOS peptide, $10 \mu \mathrm{g} / \mathrm{ml}$ of BSA or $500 \mathrm{ng} / \mathrm{ml}$ insulin. In addition, $20 \mu \mathrm{g} / \mathrm{ml}$ of PHA was used as a positive control. All variants of differently stimulated (with exception for BSA) and non-stimulated cells were applied in quadruplicates when possible. Cells were cultured undistributed for $48 \mathrm{~h}$ at $37^{\circ} \mathrm{C}$, in a humidified atmosphere with $5 \% \mathrm{CO}_{2}$ and thereafter washed. We incubated $1 \mu \mathrm{g} / \mathrm{ml}$ biotinylated anti-human IFN- $\gamma$ 1-D1KmAB and biotinylated anti-human IL-4 mAB (Mabtech $\mathrm{AB}$ ) respectively, for $2 \mathrm{~h}$ at room temperature. Streptavidin conjugated with alkaline phosphatase (Mabtech AB), diluted 1:1000, was incubated for $1 \mathrm{~h}$. Spots developed by "AP conjugate substrate kit" (Bio-Rad, Hercules, Calif., USA) were seen after 5-10 $\mathrm{min}$. The reaction was allowed to proceed for another 5 min before the wells were rinsed with excessive amounts of tap water, emptied and dried overnight at room temperature.

All plates with spots were counted manually on two different occasions, in dissection microscope, always by the same investigator. The plates were blinded for identity to avoid any influence of the outcome of the observation. The median value of the quadruplicates was calculated for each antigen and lymphocyte concentration. The value of the non-stimulated cells (the "spontaneous spots") was subtracted from the value of the stimulated cells. As a control, some wells on each plate were incubated exclusively with Iscove's modification of Dulbecco's medium with supplements, without cells but otherwise treated as the other wells, whereas stimulation with PHA was used as a positive control.

Islet cell antibodies (ICA). Islet cell antibodies were detected with immunofluorescence on human pancreas sections according to a previously reported method [30]. Our method was standardised according to the IJDF standards for ICA determination. Our laboratory has participated in international ICA workshops and has reached specificity as well as sensitivity of $100 \%$.
$G A D_{65}$-autoantibodies. The $\mathrm{GAD}_{65}$-autoantibodies were measured with a commercial RIA (RSR, Cardiff, UK). Samples were regarded as positive when more than $0.8 \mathrm{U} / \mathrm{ml}$ where intra-assay and inter-assay coefficients of variation were $2.9 \%$ and $5.1 \%$.

Coxsackie virus antibodies. We analysed $\mathrm{IgG}$ class antibodies against Coxsackievirus B4 as described previously [31]. The IgM class antibodies were measured using a heavy chain capture EIA using a cocktail of heat-treated Coxsackie B3, A16 and echo 11 viruses as antigens [31]. Antibody levels were expressed as the relative antibody activity compared with positive and negative control sera included in each assay [32]. Seropositive cut-off value for $\mathrm{IgG}$ antibody positivity was set at higher than 20 EIU (enzyme immunoassay unites). Positive IgM or a significant increase (twofold or greater) in IgG or IgM antibodies was used as an indicator of an acute enterovirus infection.

Insulin autoantibodies (IAA). Insulin autoantibodies were detected with a radioligand competition assay according to a previously described method [33]. Included in each assay was a positive control (pool of sera from three IAA-positive patients) and a negative control subject (with undetectable IAA). Results were calculated as the difference between incubation with ${ }^{125} \mathrm{I}$-insulin and incubation with ${ }^{125} \mathrm{I}$-insulin and excess of unlabelled antigen. Cut-off was set at M +2 SD for healthy control subjects $=99 \mathrm{nU} / \mathrm{ml}$.

IgG antibodies to BSA. Bovine serum albumin-antibodies were detected by ELISA. Incubation with mouse anti-human IgG (BioZac Mo6014, Järfälla, Sweden) was followed by incubation with rabbit anti-mouse ALP (Sigma A4312, Sweden). Intra-assay and inter-assay coefficients of variation for IgG antibodies were $11.2 \%$ and $13.9 \%$. Occurrence of $\mathrm{IgG}$ within the samples was calculated out of a standard curve prepared from serum with high binding to BSA.

Statistics. As the expression of mRNA for IFN- $\gamma$ and IL-4 as well as secretion of the above mentioned cytokines was not normally distributed (even after logarithmic transformation), two groups were compared with Mann-Whitney U-test and three or more groups were compared with Kruskal Wallis test for unpaired observations. Spearman's rank correlation was used when comparing two non-parametric variables whereas comparison between paired groups were analysed with Wilcoxon's signed rank test.

A probability level of less than $5 \%$ was considered to be statistically significant. Calculations were done with a statistical package StatView 5.0.1 for Macintosh (Abacus Concepts, Berkeley, Calif., USA).

Ethics. The study was approved by the research ethics committee of the Faculty of Health Sciences, Linköping University.

\section{Results}

\section{Evaluation of antigen concentration and controls}

Peptide concentration. In the initial experiments the peptides were diluted in tissue culture medium in different concentrations; $1 \mu \mathrm{g} / \mathrm{ml}, 1 \mathrm{ng} / \mathrm{ml}, 500 \mathrm{pg} / \mathrm{ml}$, $100 \mathrm{pg} / \mathrm{ml}, 50 \mathrm{pg} / \mathrm{ml}$ and $1 \mathrm{pg} / \mathrm{ml}$ and each dilution was tested by stimulating PBMC followed by detec- 
tion with the ELISPOT technique of cells secreting IFN- $\gamma$ and IL-4. An optimal concentration for all peptides and for both IFN- $\gamma$ and IL-4 was found to be $100 \mathrm{pg} / \mathrm{ml}$, which was consequently used throughout the study.

Antigen concentration. The optimal concentration for bovine serum albumin was found to be $10 \mu \mathrm{g} / \mathrm{ml}$, for insulin $500 \mathrm{ng} / \mathrm{ml}$ insulin and for the positive control PHA $20 \mu \mathrm{g} / \mathrm{ml}$ when used for analysing cytokin secretion with the ELISPOT technique.

Positive and negative controls. Stimulation with PHA, used as a positive control, always generated IFN- $\gamma$ and IL-4 spots for high-risk relatives, diabetic children and healthy control subjects. No spots were found in wells incubated exclusively with Iscove's modification of Dulbecco's medium with supplements.

Viability. The viability for all peripheral blood mononuclear cells was found between $87-98 \%$ for each population. Only one sample differed from this result showing a viability of $78 \%$.

\section{Cell-mediated immunity}

Higher ratio of IFN- $\gamma: I L-4$ in high-risk first-degree relatives of Type I diabetic patients. High-risk relatives had high spontaneous secretion of IFN- $\gamma$ compared with children with newly diagnosed Type I diabetes $(p=0.0002)$ (Fig. 1). A higher ratio of IFN$\gamma:$ IL-4 could be seen from the first-degree relatives of diabetic patients compared with diabetic children $(p=0.0005)$ and healthy control subjects $(p=0.004)$ (Fig. 1). Diabetic children as well as five high-risk relatives who became diabetic during the ENDIT-trial showed a lower ratio of IFN- $\gamma$ :IL-4 compared with those high-risk relatives who so far have remained healthy $(p=0.05)$.

The total amount of spontaneous secreted IFN- $\gamma$ was negatively correlated to the number of mononuclear cells in peripheral blood from relatives with a high risk of developing Type I diabetes $(r=-0.58$, $p=0.001)$. Spontaneous secretion of either IFN- $\gamma$ or IL-4 was not related to age within the group of highrisk relatives. Neither was the ratio of spontaneous secreted IFN- $\gamma:$ IL-4 correlated to the sex of subjects included in this trial.

Reaction to specific peptides of $G A D_{65}$. Secretion of IFN- $\gamma$, which was extremely high in the subjects included in the ENDIT-trial, did not further increase after stimulation with specific peptides (Table 1). Stimulation with the three specific peptides from $\mathrm{GAD}_{65}$ (a.a. 247-279, 509-528 and 524-543) led to decreased amounts of IFN- $\gamma$ within the group of

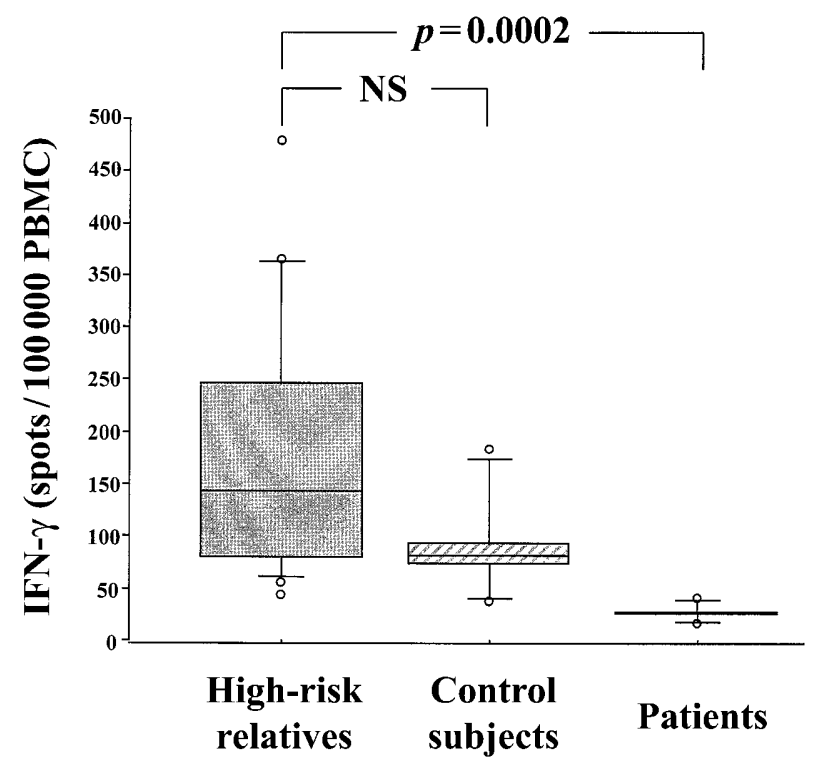
A $n=$
21
6
6

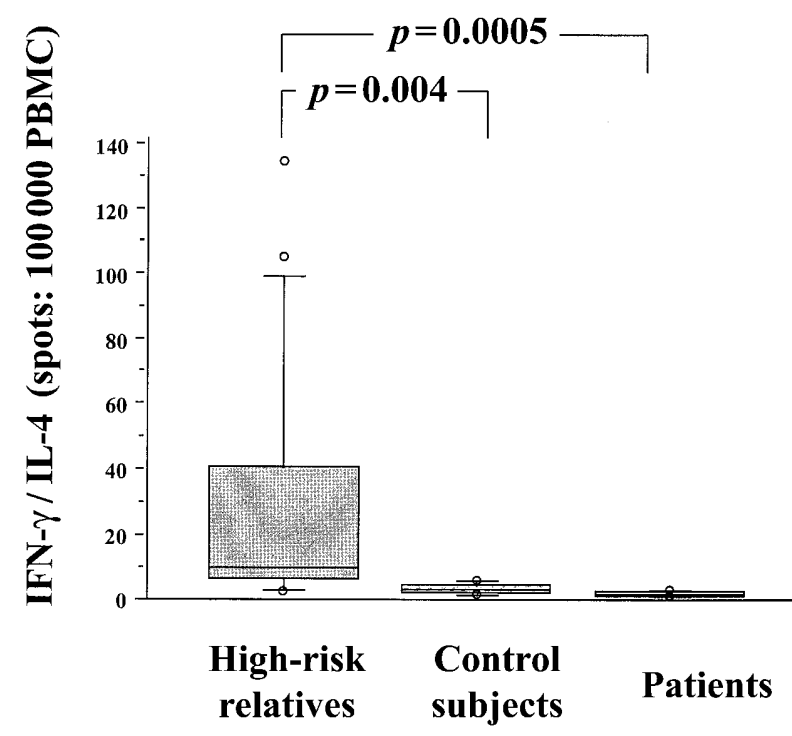

B $\quad n=$

21

6

6

Fig. 1. A Significantly higher spontaneous secretion of IFN- $\gamma$ among high-risk relatives compared to patients with diabetes. Secretion of IFN- $\gamma$ is calculated as spots/100 000 PBMC and illustrated by centile box plot (10th, 25th, 50th, 75th and 90th centile and outliers are indicated). B Relatives at high-risk of developing Type I diabetes show a high ratio of IFN- $\gamma$ :IL-4 compared with diabetic patients and healthy control subjects. The ELISPOT technique is done to calculate the number of cytokine secreting cells:100 000 PBMC illustrated by centile box plot

high-risk relatives $(p<0.0001)$. This significant down-regulation of IFN- $\gamma$ production could not be seen in either children with newly diagnosed Type I diabetes or in healthy control subjects except when stimulated with $\mathrm{GAD}_{65}$ (a.a. 524-543) which caused decreased IFN- $\gamma$ release in Type I diabetic children 
Table 1. Secretion of IFN- $\gamma$ and IL-4

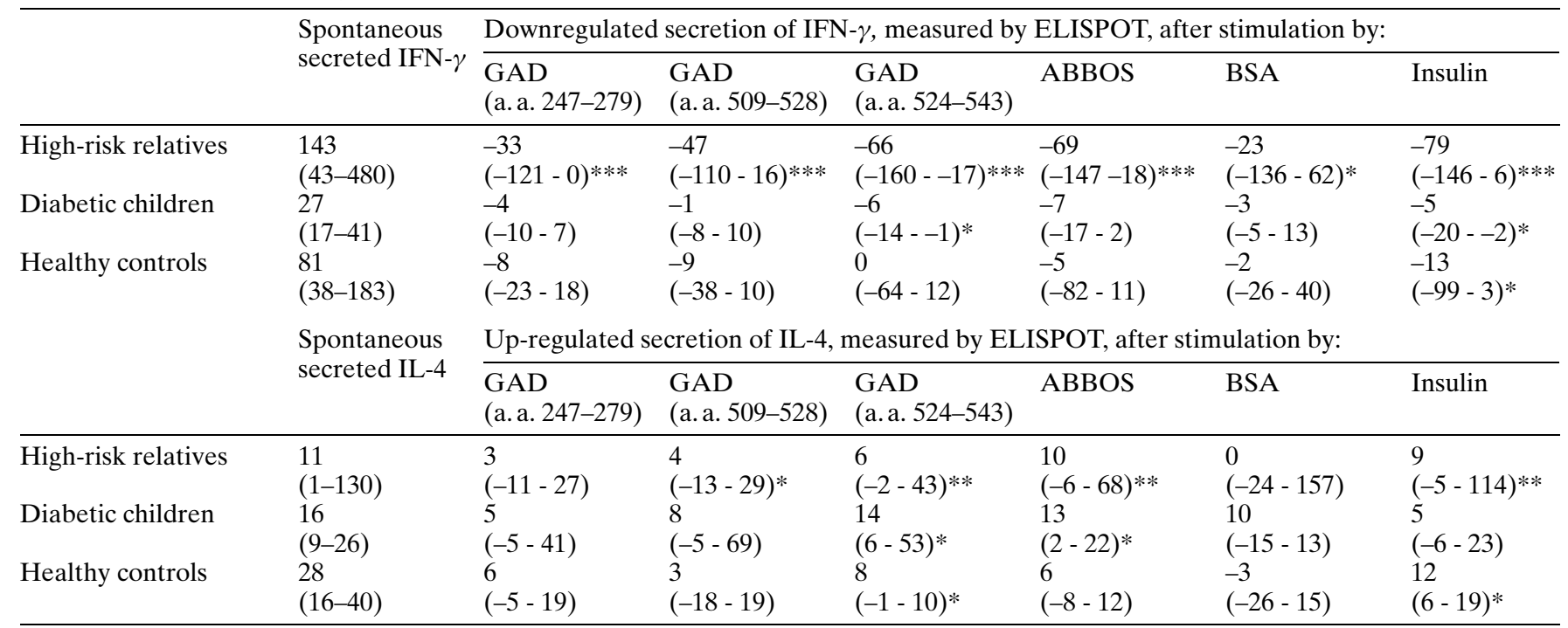

Secretion of IFN- $\gamma$ and IL-4 after stimulation with antigens calculated as spots/100 000 PBMC after subtraction of spontaneous cytokine secretion illustrated as median and extremes (within brackets). $P$ value represents significantly down-regu- lated secretion of IFN- $\gamma$ and up-regulated secretion of IL-4 by antigen stimulation among high-risk relatives, diabetic children and healthy control subjects. $* * * p<0.0001$, $* * p \leq 0.001$, $* p<0.05$ $(p<0.05)$. The low spontaneous secretion of IL-4 increased instead after stimulation with $\mathrm{GAD}_{65}$ (a.a. 509-528 and a.a. 524-543) in high-risk relatives $(p<0.05$ and $p=0.0007$, respectively). In the same way $\mathrm{GAD}_{65}$ (a. a. 524-543) stimulated PBMC to IL-4 production in Type I diabetic children $(p<0.05)$ as well as in healthy control subjects $(p<0.05)$.

Reaction to BSA and the ABBOS peptide. High-risk relatives and healthy control subjects showed equal expression of IFN- $\gamma$ and IL-4 mRNA after specific stimulation with the ABBOS peptide (a.a. 32-47) from BSA. The ABBOS peptide caused, however, decreased secretion of IFN- $\gamma$ in combination with an up-regulated IL-4 response in high-risk relatives $(p<0.0001, p=0.0003$, respectively), an increased IL-4 response in diabetic subjects $(p<0.05)$ but no further response in healthy control subjects (Table 1). Bovine serum albumin also caused decreased production of IFN- $\gamma(p<0.05)$ but no increased production of IL-4 in high-risk relatives, although it did not cause either secretion of IFN- $\gamma$ or IL- 4 in diabetic children or in healthy control subjects (Table 1).

Reaction to insulin. Decreased secretion of IFN- $\gamma$ after stimulation with insulin could be seen both in the high-risk relatives $(p<0.0001)$ as well as in the diabetic children $(p<0.05)$ and the healthy control subjects $(p<0.05)($ Table 1$)$. This phenomena was seen in combination with an increased production of IL-4 in the high-risk relatives $(p=0.0013)$ and in the healthy control subjects $(p=0.03)$ (Table 1$)$.

\section{Humoral immunity}

Autoantibodies against $\mathrm{GAD}_{65}$ could be detected in 15 out of 20 high-risk relatives. Low levels of $\mathrm{GAD}_{65}$ autoantibodies were seen in the high-risk relatives who tended to produce more IFN- $\gamma(r=-0.44$, $p=0.05$ ) (Fig.2). The appearance of ICA, IAA or BSA antibodies among high-risk relatives was not related to either spontaneous secretion of IFN- $\gamma$ or IL-4.

A recent Coxsackie B4 virus infection indicated by a significant twofold increased IgG and IgM positivity for a cocktail of Coxsackie A16 and B3 and Echovirus 11 could be seen in one 12-year-old boy. In addi-

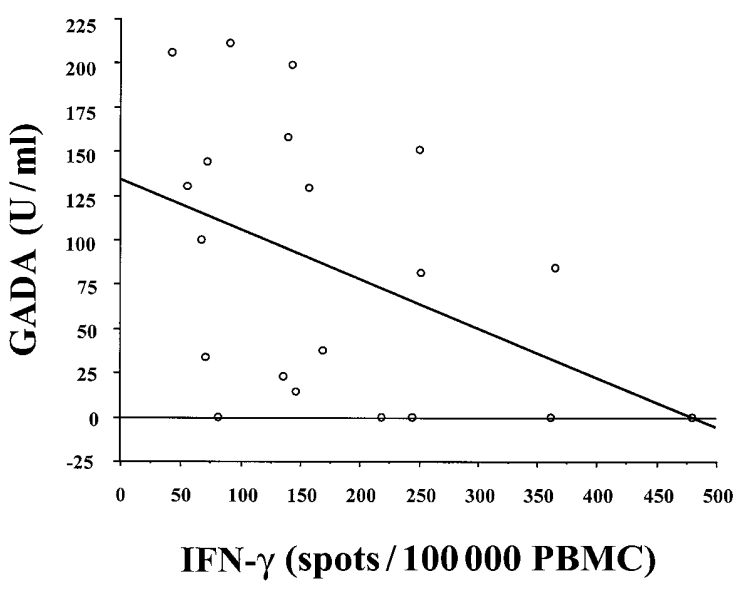

Fig. 2. Decreased level of GAD autoantibodies (U/ml) studied in high-risk relatives who secrete high amounts of IFN- $\gamma$ spontaneously. $r=-0.44, p=0.05, n=20$ 
Table 2. Expression of IFN- $\gamma$ and IL-4 mRNA

Upregulated IFN- $\gamma$ mRNA expression, measured by RT-PCR, after stimulation with:

\begin{tabular}{llll}
\cline { 2 - 3 } & $\begin{array}{l}\text { GAD } \\
\text { (a.a. 247-279) }\end{array}$ & ABBOS & Insulin \\
\hline High-risk relatives & $7(19)$ & $9(17)$ & $3(19)$ \\
Diabetic children & N.D. & N.D. & N.D. \\
Healthy controls & $0(6)$ & $2(6)$ & N.D.
\end{tabular}

Upregulated IL-4 mRNA expression, measured by RT-PCR, after stimulation with:

\begin{tabular}{llll}
\cline { 2 - 4 } & $\begin{array}{l}\text { GAD } \\
\text { (a.a. 247-279) }\end{array}$ & ABBOS & Insulin \\
\hline High-risk relatives & $3(19)$ & $5(17)$ & $4(19)$ \\
Diabetic children & N.D. & N.D. & N.D. \\
Healthy controls & $0(6)$ & $2(6)$ & N.D. \\
\hline
\end{tabular}

Expression of IFN- $\gamma$ and IL-4 mRNA after stimulation with antigens scored as constant or up-regulated expression after subtraction of mRNA expression detected from unstimulated PBMC. Values represent number of subjects in which stimulation with antigen caused up-regulated cytokine mRNA expression among those studied (within brackets). ND = not detected

tion one woman had an ongoing infection indicated by high IgG and positive IgM. High amounts of ICAs $(r=0.533, p=0.03)$ were found in the highrisk relatives who produced Coxsackie B4 IgG antibodies.

\section{Discussion}

Our major finding is a significantly higher secretion of IFN- $\gamma$ among subjects with a high risk of developing Type I diabetes than in diabetic patients. These high-risk subjects also have a significantly higher ratio of IFN- $\gamma:$ IL-4. Studies in NOD mice $[34,35]$ as well as in Type I diabetic patients, support the promotion of inflammatory cellular immune responses by Th1 cells and are biased towards secretion of IFN $-\gamma$, TNF- $\beta$ and IL-2 [36]. A current hypothesis is that the pathogenic immune response is mediated by Th1 cells whereas the protective immune response is mediated by Th 2 cells [35]. Concentrations of circulating monocyte (IL-1 $\alpha$, TNF- $\alpha$ ) and Th1 subset cytokines (IL-2, IFN- $\gamma$ ) are increased in patients at the time of diagnosis of Type I diabetes $[37,38]$. By contrast, production of Th2 cytokines (IL-4, IL-10) is not increased, in keeping with the proposal that a Th1dominant immune response plays a central part in disease pathogenesis $[38,39]$.

The high concentration of IFN- $\gamma$ from high-risk subjects did not further increase after stimulation with antigens. The peptide from $\mathrm{GAD}_{65}$ (a.a. 247-279), which mimics the Coxsackie B virus, decreased the amount of IFN- $\gamma$ within this group. Fur- thermore, the $\mathrm{GAD}_{65}$-peptide (a.a. 509-528) which share sequence homology with a number of viruses but also with proinsulin caused decreased secretion of IFN- $\gamma$ in the high-risk group. The first-mentioned peptide of $\mathrm{GAD}_{65}$ did not cause production of IL-4 whereas the second peptide caused up-regulated secretion of IL-4. The third peptide of $\mathrm{GAD}_{65}$ (a.a. 524-543) which might be immunodominant for Type I diabetes, caused decreased secretion of IFN- $\gamma$ in high-risk subjects as well as in diabetic children. This peptide furthermore caused up-regulated amounts of IL-4 in subjects with high risk for diabetes, in diabetic patients as well as in healthy control subjects. Nasal insertion of $\mathrm{GAD}_{65}$ peptides could induce a Th2 cell response that inhibits the spontaneous development of autoreactive Th1 responses and the progression of beta-cell autoimmunity in NOD mice [40]. Active cellular suppression linked to a shift of the Th1:Th2 balance towards production of Th2 cytokines by immunisation of NOD mice with $\mathrm{GAD}_{65}$ (a.a. 524-543) has been reported [17]. Epitope-specific therapy by T-cell epitopes of $\mathrm{GAD}_{65}$, especially amino acids 524-543 [16], is furthermore suggested to be of importance for the design of therapeutic approaches in human diabetes [41].

Autoantibodies against $\mathrm{GAD}_{65}$ (GADA) are supposed to be able to delay the onset of Type I diabetes [39]. The high-risk subjects included in this study who produced low concentrations of GADA secreted high amounts of IFN- $\gamma$ spontaneously. Furthermore, association between Coxsackie viral infection and Type I diabetes remains controversial despite nearly 40 years of supportive epidemiological data. Of the high-risk subjects two showed signs of a recent Coxsackie B4 virus infection but no distinct cytokine profile. This observation does not therefore provide evidence of an important link between the existence of a causative environmental agent and an immunological effector system.

Bovine serum albumin decreased the secretion of IFN- $\gamma$ only in high-risk subjects whereas this protein did not stimulate the Th2-like lymphocytes to secret IL-4. Nevertheless, the milk-derived bovine serum albumin-peptide ABBOS down-regulated the cytokine production in Th1-like lymphocytes only in high-risk subjects whereas both these subjects and the diabetic children responded to this specific peptide with increased production of IL-4. Proliferation of PBMC to BSA has been reported from patients with diabetes compared with non-responding healthy control subjects [22] and furthermore to the specific ABBOS peptide [18]. In contrast, other investigations have found no proof of a difference in humoral or cellular response to BSA between newly diagnosed patients with diabetes and healthy adults $[42,43]$. This latter finding is in agreement with our previous finding showing both Th1-like and Th2-like immune activation in diabetic children as well as healthy control 
subjects after stimulation with the ABBOS peptide [20].

Treatment with insulin by a variety of routes has been shown to prevent the onset of diabetes and the destruction of pancreatic beta-cells in prediabetic animals [44] and in high-risk first-degree relatives [45]. It has been suggested that giving insulin orally affects the development of diabetes in NOD mice through the generation of cells that elaborate immunoregulatory cytokines within the target organ and shift the balance from a Th1 to a Th2 pattern of cytokine expression [46]. Insulin used as an antigen within our study caused a decline in the Th1-like response but increased activation of Th2-like lymphocytes in the group of high-risk subjects. Up-regulated secretion of IL-4 produced by Th2-like lymphocytes after treatment with insulin might indicate that insulin could have an immune suppressive effect in high-risk subjects.

Cytokines are highly interdependent and the responses of Th1 and Th2 cells are mutually inhibitory $[3,47,48]$. Thus, suppression of IFN- $\gamma$ production is a recognised action of both IL-4 and IL-10 [49-51]. This could be one possible explanation for the cytokine secretion seen after specific antigen-stimulation in peripheral blood mononuclear cells from subjects at increased risk for Type I diabetes.

This study illustrates an overwhelming production of IFN- $\gamma$ secreted from relatives with high-risk of developing Type I diabetes in combination with decreased amount of autoantibodies against $\mathrm{GAD}_{65}$. The results might reflect a Th1-like immune deviation in the prediabetic phase of people at high-risk of developing Type I diabetes.

Acknowledgements. This study has been generously supported by the Söderberg Foundation, Swedish Medical Research Council (No. K99-72X-11242-05A), Novo Nordisk Research Fund, JDF-Wallenberg (No. K98-99JD-12813-01A), Medical Research Fund of the County of Östergötland, Samaritens' Foundation, The Swedish Diabetes Foundation, The Swedish Child Diabetes Foundation and the Queen Silvia's Jubilee Fund. The laboratory work was done at the Clinical Research Centre of the Faculty of Health Sciences. We thank A. Rosdahl and S. Hellström for skillful technical assistance and we gratefully acknowledge H. Hyöty for analyses of CBV antibodies. C. Ekerfelt and M. Widhe are gratefully acknowledged for their guidance throughout the ELISPOT technique.

Co-authors participating in the Swedish ENDIT-group. H. Edenwall, MD, Karlskrona; R. Hanås, MD, Uddevalla; H. Hörnell, MD, Hudiksvall; C. Johansson, MD, Jönköping; G. Jonsell, MD, Karlstad; K. Larsson, MD, Kristianstad; J. Neiderud, MD, Helsingborg; N.-Ö. Nilsson, MD, Halmstad; L. Stenhammar, MD, Norrköping; S. Sjöblad, MD, Lund; L. Skogsberg, MD, Boden; K. Snellman, MD, Falun

\section{References}

1. Bottazzo GF, Dean BM, McNally JM, MacKay EH, Swift PGF, Gamble DR (1985) In situ characterization of autoimmune phenomena and expression of HLA molecules in the pancreas in diabetic insulitis. N Engl J Med 313: 353-360

2. Castano L, Eisenbarth GS (1990) Type-I diabetes: A chronic autoimmune disease of human, mouse and rat. Annu Rev Immunol 8: 647-679

3. Mosmann TR, Coffman RL (1989) TH1 and TH2 cells: Different patterns of lymphokine secretion lead to different functional properties. Ann Rev Immunol 7: 145-173

4. Liblau RS, Singer SM, McDevitt HO (1995) Th1 and Th2 CD4 + T cells in the pathogenesis of organ-specific autoimmune diseases. Immunol Today 16: 34-38

5. Song YH, Li Y, Maclaren NK (1996) The nature of autoantigens targeted in autoimmune endocrine diseases. Immunol Today 17: 232-238

6. Baekkeskov S, Landin M, Kvist Kristensen J et al. (1987) Antibodies to a $64,000 \mathrm{Mr}$ human islet cell antigen precede the clinical onset of insulin-dependent diabetes. J Clin Invest 79: 926-934

7. Baekkeskov S, Aanstoot H-J, Christgau S et al. (1990) Identification of the $64 \mathrm{~K}$ autoantigen in insulin-dependent diabetes as the GABA-synthesizing enzyme glutamic acid decarboxylase. Nature 347: 151-156

8. Kaufman DL, Erlander MG, Clare-Salzler M, Atkinson MA, Maclaren NK, Tobin AJ (1992) Autoimmunity to two forms of glutamate decarboxylase in insulin-dependent diabetes mellitus. J Clin Invest 89: 283-292

9. Richter W, Shi Y, Baekkeskov S (1993) Autoreactive epitopes defined by diabetes-associated human monoclonal antibodies are localized in the middle and C-terminal domains of the smaller form of glutamate decarboxylase. Proc Natl Acad Sci USA 90: 2832-2836

10. Atkinson MA, Bowman MA, Campbell L, Darrow BL, Kaufman DL, Maclaren NK (1994) Cellular immunity to a determinant common to glutamate decarboxylase and coxsackie virus in insulin-dependent diabetes. J Clin Invest 94: 2125-2129

11. Schloot NC, Roep BO, Wegmann DR (1997) T-cell reactivity to GAD65 peptide sequences shared with coxsackie virus protein in recent-onset IDDM, post-onset IDDM patients and control subjects. Diabetologia 40: 332-338

12. Karlsson MGE, Ludvigsson J (1998) Determination of mRNA expression for IFN- $\gamma$ and IL-4 in lymphocytes from children with IDDM by RT-PCR technique. Diabetes Res Clin Pract 40: 21-30

13. Karlsson MGE, Ludvigsson J (1998) Peptide from glutamic acid decarboxylase similar to coxsackie B virus stimulates IFN- $\gamma$ mRNA expression in Th1-like lymphocytes from children with recent-onset insulin-dependent diabetes mellitus. Acta Diabetol 35: 137-144

14. Jones DB, Crosby I (1996) Proliferative lymphocyte responses to virus antigens homologous to GAD65 in IDDM. Diabetologia 39: 1318-1324

15. Rudy G, Stone N, Harrison LC et al. (1995) Similar peptides from two beta cell autoantigens, proinsulin and glutamic acid decarboxylase, stimulate $\mathrm{T}$ cells of individuals at risk for insulin-dependent diabetes. Mol Med 1: 625-633

16. Lohmann T, Leslie RDG, Hawa M, Geysen M, Rodda S, Londei M (1994) Immunodominant epitopes of glutamic acid decarboxylase 65 and 67 in insulin-dependent diabetes mellitus. Lancet 343: 1607-1608 
17. Sai P, Rivereau AS, Granier C, Haertlé T, Martignat L (1996) Immunization of non-obese diabetic (NOD) mice with glutamic acid decarboxylase-derived peptide 524-543 reduces cyclophosphamide-accelerated diabetes. Clin Exp Immunol 105: 330-337

18. Karjalainen J, Martin JM, Knip M et al. (1992) A bovine albumin peptide as a possible trigger of insulin-dependent diabetes mellitus. N Engl J Med 327: 302-307

19. Martin JM, Trink B, Daneman D, Dosch H-M, Robinson B (1991) Milk proteins in the etiology of insulin-dependent diabetes mellitus (IDDM). Ann Med 23: 447-452

20. Karlsson MGE, Ludvigsson J (2000) The ABBOS-peptide from bovine serum albumin causes an IFN- $\gamma$ and IL4 mRNA response in lymphocytes from children with recent onset of type 1 diabetes. Diabetes Res Clin Pract 47: 199-207

21. Gale EAM (1996) Molecular mechanisms of beta-cell destruction in IDDM: the role of nicotinamide. Horm Res 45: 40-43

22. Cheung R, Karjalainen J, Vandermeulen J, Singal DP, Dosch H-M (1994) T cells from children with IDDM are sensitized to bovine serum albumin. Scand J Immunol 40: 623-628

23. Worsaae A, Hejnaes K, Moody A et al. (1995) T cell proliferative responses to glutamic acid decarboxylase-65 in IDDM are negatively associated with HLA DR3/4. Autoimmunity 22: 183-189

24. Hallewell RA, Masiarz FR, Najarian RC et al. (1985) Human $\mathrm{Cu} / \mathrm{Zn}$ superoxide dismutase cDNA: isolation of clones synthesising high levels of active or inactive enzyme from an expression library. Nucleic Acids Res 13: 2017-2034

25. Arai N, Nomura D, Villaret D et al. (1989) Complete nucleotide sequence of the chromosomal gene for human IL4 and its expression. J Immunol 142: 274-282

26. Gray PW, Goeddel DV (1982) Structure of the human immune interferon gene. Nature 298: 859-863

27. Tang H, Matthes T, Carballido-Perrig N, Zubler RH, Kindler V (1993) Differential induction of $\mathrm{T}$ cell cytokine mRNA in Epstein-Barr virus-transformed B cell clones: constitutive and inducible expression of interleukin4 mRNA. Eur J Immunol 23: 899-903

28. Czerkinsky C, Tarkowski A, Nilson L- $\AA$ (1984) Reverse enzyme-linked immunospot (RELISPOT) assay for detection of cells secreting immunoreactive substances. J Immunol Methods 72: 489-496

29. Ekerfelt C, Ernerudh J, Bunikis J et al. (1997) Compartmentalization of antigen specific cytokine responses to the central nervous system in CNS borreliosis: Secretion of IFN- $\gamma$ predominates over IL-4 secretion in response to outer surface proteins of Lyme disease Borrelia spirochetes. J Neuroimmunol 79: 155-162

30. Bottazzo GF, Florin-Christensen A, Doniach D (1974) Islet-cell antibodies in diabetes mellitus with autoimmune polyendocrine deficiencies. Lancet ii: $1279-1283$

31. Juhela S, Hyöty H, Hinkkanen A et al. (1999) T-cell responses to enterovirus antigens and to beta-cell autoantigens in unaffected children positive for IDDM-associated autoantibodies. J Autoimmun 12: 269-278

32. Hyöty H, Hiltunen M, Knip M et al. (1995) A prospective study of the role of Coxsackie B and other enterovirus infections in the pathogenesis of IDDM. Diabetes 44: 652-657

33. Palmer JP, Asplin CM, Clemons P et al. (1983) Insulin antibodies in insulin-dependent diabetics before insulin treatment. Science 222: 1337-1339
34. Tisch R, Yang X-D, Singer SM, Liblau RS, Fugger L, McDevitt HO (1993) Immune response to glutamic acid decarboxylase correlates with insulitis in non-obese diabetic mice. Nature 366: 72-75

35. Rabinovitch A (1994) Immunoregulatory and cytokine imbalances in the pathogenesis of IDDM. Diabetes 43: 613-621

36. Kallmann BA, Hüther M, Tubes M et al. (1997) Systemic bias of cytokine production toward cell-mediated immune regulation in IDDM and toward humoral immunity in Graves' disease. Diabetes 46: 237-243

37. Espersen GT, Mathiesen O, Grunnet N, Jensen S, Ditzel J (1993) Cytokine plasma levels and lymphocyte subsets in patients with newly diagnosed insulin-dependent (type 1) diabetes mellitus before and following initial insulin treatment. APMIS 101: 703-706

38. Hussain MJ, Peakman M, Gallati H et al. (1996) Elevated serum levels of macrophage-derived cytokines precede and accompany the onset of IDDM. Diabetologia 39: 60-69

39. Harrison LC, Honeyman MC, DeAizpurua HJ et al. (1993) Inverse relation between humoral and cellular immunity to glutamic acid decarboxylase in subjects at risk of insulindependent diabetes. Lancet 341: 1365-1369

40. Tian J, Atkinson MA, Clare-Salzler M et al. (1996) Nasal administration of glutamate decarboxylase (GAD65) peptides induces $\mathrm{Th} 2$ responses and prevents murine insulindependent diabetes. J Exp Med 183: 1561-1567

41. Lohmann T, Scherbaum WA (1996) T cell autoimmunity to glutamic acid decarboxylase in human insulin-dependent diabetes mellitus. Horm Metab Res 28: 357-360

42. Atkinson MA, Bowman MA, Kao KJ et al. (1993) Lack of immune responsiveness to bovine serum albumin in insulin-dependent diabetes. N Engl J Med 329: 1853-1858

43. Vaarala O, Klemetti P, Savilahti E, Reijonen H, Ilonen J, Åkerblom HK (1996) Cellular immune response to cow's milk $\beta$-lactoglobulin in patients with newly diagnosed IDDM. Diabetes 45: 178-182

44. Karounos DG, Bryson JS, Cohen DA (1997) Metabolically inactive insulin analog prevents type 1 diabetes in prediabetic NOD mice. J Clin Invest 100: 1344-1348

45. Füchtenbusch M, Rabl W, Grassl B, Bachmann W, Standl E, Ziegler A-G (1998) Delay of Type I diabetes in high risk, first degree relatives by parenteral antigen administration: the Schwabing insulin prophylaxis pilot trial. Diabetologia 41: 536-541

46. Hancock WW, Polanski M, Zhang J, Blogg N, Weiner HL (1995) Suppression of insulitis in non-obese diabetic (NOD) mice by oral insulin administration is associated with selective expression of interleukin- 4 and -10 , transforming growth factor- $\beta$ and prostaglandin-E. Am J Pathol 147: 1193-1199

47. Romagnani S (1992) Human TH1 and TH2 subsets: Regulation of differentiation and role in protection and immunopathology. Int Arch Allergy Immunol 98: 279-285

48. Powrie F, Coffman RL (1993) Cytokine regulation of T-cell function: potential for therapeutic intervention. Immunol Today 14: 270-274

49. Fitch FW, McKisic MD, Lancki DW, Gajewski TF (1993) Differential regulation of murine $\mathrm{T}$ lymphocytes subsets. Annu Rev Immunol 11: 29-48

50. Seder RA, Paul WE (1994) Acquisition of lymphokineproducing phenotype by CD4 + T cells. Annu Rev Immunol 12: 635-673

51. Moore KV, O'Garra A, de Waal Malefyt R, Vieira P, Mosmann TR (1993) Interleukin 10. Annu Rev Immunol 11: 165-190 